\title{
Teachers' Perspective on the Importance of Parents' Roles in Students' Academic Achievement Using School and Family Partnership Model (Epstein): A Qualitative Study
}

\author{
Shanti Ramanlingam, Mahendran Maniam* \\ Department of English Language and Literature, Faculty of Languages and Communication, Sultan Idris Education University
} (UPSI), Malaysia

Received March 21, 2020; Revised May 5, 2020; Accepted May 20, 2020

Copyright $\odot 2020$ by authors, all rights reserved. Authors agree that this article remains permanently open access under the terms of the Creative Commons Attribution License 4.0 International License

\begin{abstract}
This study aims to identify the importance of parental involvement in student academic achievement in Primary School in Selangor through school, family and community partnership from teacher's perspective. It focused on the involvement of parents based on six main aspects of Epstein's model i.e. parenting, communication, home-based learning, decision-making, community collaboration and volunteerism. These aspects enable parents' involvement and collaboration with schools and outside communities in order to improve students' academic achievement. This study used a qualitative method, where questionnaire and respondent interviews were used as the research instrument. Snowball sampling was used and a total of four primary school headmasters from high- and low-performing schools were interviewed using a naturalistic investigation technique with an open-ended semi-structured questionnaire containing 10 items in two domains. The purpose of this study was to obtain the information needed to understand parents' perceptions of the importance of their involvement in improving student academic achievement and the collaboration required among schools, families and the community. The data obtained was analyzed using Thematic analysis. The findings showed that, there was a significant positive relationship between parents' involvement and the improvement of academic achievement of the students, namely in the aspects of home teaching, parenting, decision-making and volunteerism. As a conclusion, some new suggestions were made to enhance the involvement of parents in the academic achievement of the Tamil school students.
\end{abstract}

Keywords Academic Achievement, Epstein Model, Parent Involvement

\section{Introduction}

Education is a gift to improve and enhance the social and economy standard of individuals with their own efforts (Amin, 1998). Academic excellence is the basis for measuring the success of a student in all stages of schooling, right until the Higher Education Institutions (Epstein, 1993). It is often associated with good results accompanied by their earnest efforts to keep up the excellent results. This academic excellence will not come rolling up, it can only be obtained with effort and self-efficacy (Comer, 2005). However, in order to achieve this outstanding success, students' efforts alone will certainly be not enough. The role of various parties, especially teachers and parents, is crucial in influencing the learning process today (Noraini, 2002). Parents and teachers play an important role, especially in bilateral communication where it can also create a situation that can control education at the basic level (Gutman and Midgley, 2004). In Malaysia, most teachers recognize that parents should be more exposed by involving them in the process of teaching their children all the time. The perception of most teachers on the role and function of parents in the Association of Parents and Teachers is at a moderate level (Merton, 2006). Teachers have become increasingly aware that parental involvement in academics has proven to improve student achievement as reported by Chavkin and Gonzalez (2005). Without the cooperation of both parties, namely, teachers and parents, the goal to have the desired impacts on the student academic 
achievement will not be attained. Therefore, teacher-parent collaboration is crucial to ensure the students' success in education (Epstein, 2015).

The outcome of this collaboration will benefit the school in facing and overcoming the challenges of the new era, such as the achievement of Vision 2020's goals as well as the High-Performing Schools and Cluster Schools.

\section{Research Problem}

The Malaysian education system practices a centralized policy where schools are controlled by a major body, the Ministry of Education. However, the centralized system rarely emphasizes the involvement of parents, families, communities and outside environment in the school operations management. This is more prominent among Tamil schools, especially those in the State of Selangor, due to several factors, including the role of the school itself which lacks comprehensive school-based programmes, teachers whose work do not involve parents in their programmes, as well as the parents themselves, who are not interested in getting involved in school-sponsored programmes. Apart from this, the professors and teachers' perceptions of the concept of partners and the importance of parent involvement may indirectly restrict the cooperation between schools and families in Tamil schools. Parental involvement among the Indian ethnics in their children's education process was found to be very low due to the economic gap which is also a factor contributing to the increasing percentage of their youths being involved in illegal activities. This reflects the lack of guidance from these parents and their community towards this group (Dhanapal, 2007). Epstein (2001) stated that, schools required parents and families to share their responsibilities in the education of children. While some studies focused on certain aspects of parent involvement, such as the roles of school as educators, the role of school PIBGs, types of parent involvement practices, and barriers to parenting were conducted in Malaysia (Razali, 2007), only a handful of them were developed with a focus on minority groups, especially the Indians. Based on the studies conducted on the ethnic Indian community, it was found that, most of them focused on farming life poverty (Marimuthu, 1990) and studies on farm labourers (Anbalakan, 2008).

There is little attention given to education. If any, studies on education are more about the status and roles of the SJK (T) in the estates (Santhiram, 1999). This was also emphasized by the Education Minister Mahdzir Khalid (2016) on the issue of parent involvement in school activities across the country where according to him, the latest statistics show that, the involvement of parents in Tamil schools varies with states, some reaching 50 percent, while some others only 40 percent. The statistics indicates that, a satisfactory level has not been achieved and further improvements must be made in the future. He also pointed out that, the roles of parents today are not limited to taking children's report cards, as they are also required to be actively involved in the school activities.

The results of Primary School Assessment Examination (UPSR) among Tamil schools nationwide for 2016, after the new format was introduced, showed that only 161 students out of a total of 14,674 candidates passed with flying colours (Tamil School Management Unit, KPM, 2016). Therefore, it is the right time now to strengthen parental involvement in improving academic achievement as stated in Malaysia Education Development Plan Element 9- Engagement of Parents, Community and Public Sector (2012) (Personal Communication, April 11, 2016, Mr. Chandran, Chairman of MGBT, Malaysia).

Hence, this problem must be attended to with the emphasis to ensure the effectiveness of collaboration among school, family and community for a holistic academic achievement. This study proposed for an investigation of the perceptions of school principals and teachers in the concept of co-operation and their perception of the importance of parent involvement in the education of their children in Tamil schools. This was also an attempt to identify parent involvement on student academic achievement.

\section{Significance of the Research}

In this study, the emphasis was given to understand the ways schools and family collaboration could be carried out by examining the perceptions of the professors and teachers on the concept of cooperation and their perceptions of the importance of parent involvement in the education of children. This study can also provide real information to researchers on parents' and teachers' perceptions, school's importance and practice, and collaboration on parent involvement in improving students' academic achievement in Tamil schools. It also helps to guide the relationship between teachers and parents, in terms of encouraging more active involvements of parents in helping students to improve their academic achievement in Tamil schools.

This study will be submitted to the Curriculum Division Planners and the Ministry of Education staff, especially the Teacher Education Division for their evaluation and actions to include parent involvement courses in pre-service training and in teacher services. In addition, this study will also be submitted to the School Administration Training Institutes such as Aminuddin Baki Institute and Council of Headmasters, so that the information gathered can be used to train school administrators and provide knowledge and skills for school principals to work together with parents in children 
education.

Thus, the commitment of teachers and parents through the concept of shared responsibility is expected to result in technologies which support Cluster Schools and High Performance Schools as part of the improvement of the Malaysian Education Development Plan (2013 - 2025) education strategy. This will certainly help to improve the Malaysian education system while assisting the country in achieving Vision 2020.

\section{Literature Review}

Education is a gift to improve and enhance the social and economy standard of an individual with their own effort Comer \& Haynes (2002). Many researchers (Coleman et.al, 2002) have testified that there are several variables that contribute to the success of a student's academic achievement. Among the variables that were mentioned, roles of teachers, involvement of parents and schools are regarded as the main organization. Clark (2015) associated an individual success despite the gender, social and economy standard with one's dedication towards their education. Noraini (2002) indicated that the success of an individual is contributed not only by the individual themselves but by other variables such as parents influence in today's learning process. Colemen et. al in 1966 supported the role of schools by stating that school is also the main organization that is responsible to educate and shape students to face their future.

However, looking at school as an organization, it links the roles of the school workforce especially the academic staff (teachers) as the most important variable that contribute to the advancement of students' education. The perception differs in Malaysia. The importance of teacher and parent's cooperation are not being emphasized as what have been done by its western counterpart. According to Norlizah (2008) parent's involvement is merely in the Parents-Teachers Association meet (PTA). However, now there is an increase of awareness from teachers towards the positive impact that parent's involvement have in increasing students' academic achievement. Parents also should have the knowledge and awareness about the importance of their children's education, so that, they can provide an ideal learning environment at home. Teachers, in turn, play a direct role in helping parents develop parenting knowledge through guidance provided in workshops and motivational programmes (Eccles \& Harold, 1996).

Dauber and Epstein (1993) in their study distinguished that perception and teachers' practices have more influence on parents than the students' grades, parents' education, family size and parents' judgments towards children academic ability. Several studies also discussed on the different impact that active versus passive involvement of parents have in children education. The
Joyce Epstein Model (1997, 2005) will be used in the research to show the important of parents' involvement and its dependency in school roles. Other than that, roles and cooperation shown by the community as well as the school is expected to influence parents' involvement in their children achievement. The theory has six main approaches which will be discussed in implicating the involvement of parents and partnership that is shared among school, family and community according to Epstein Model in primary schools towards academic achievement.

The objectives of this study were to evaluate the level of collaboration through the involvement of parents, schools and the community in improving student academic achievement, to identify factors contributing to student academic achievement, to analyze the effectiveness of factors contributing to parental involvement in student academic achievement, to assess the relationships between parental involvement and student academic achievement to identify factors which influence the academic achievement of students in SJKT in Selangor, Malaysia and to adapt the Epstein Model in line with the needs of SJKT in Malaysia.

\section{Methodology}

This survey used a qualitative method and the selection of the respondents was made using snowball sampling, identified through suggestions made by previous respondents. Information from the first respondent enabled the researcher to identify information gaps which would be helpful in identifying the subsequent interview respondents. The interview process ended when the data or information obtained was saturated. If the information from a particular respondent differed from that of the previous respondent, it indicated that the information gap had been met and the research had reached a saturation point. Therefore, the number of respondents was limited to 4 for this phase.

All the respondents were interviewed based on the open-ended semi-structured questionnaire. The interview was done in accordance with guidelines specifically designed for this study, in the form of a list of questions, follow-up, frameworks and sequences of questions for consistent purposes throughout the interview session.

The guideline handbook has 3 sections; The first section contains information such as time, date and venue of the interview and basic demographic information about respondents The second section contains the interview questions, the resolution of a question or statement, and expected follow-up questions, including questions about awareness and basic understanding of parental roles, as well as the impact on students' academic success. The questionnaire consists of two parts; i) Parental involvement through cooperation with the school and the 
community to enhance student academic achievement (Parenting, Communication, Decision making, Learning at home, Volunteering and Collaboration with the community), ii) The needs to achieve academic excellence with 4 items (Parenting Style, Motivation, Personality and Learning Style). At the end of the interview guide, there is space for note-taking after the interview for detail feelings, interpretations, and comments. The duration of each interview is between 60 and 150 minutes.

Upon completion of the interviews, the recorded conversations were transcribed in Malay text. As for some conversations in Tamil and English, the text was written in the spoken languages, before being translated into Malay. Subsequently, Thematic analysis was performed, where a Thematic code was used to record the interview findings, before patterns were formed for the description of these findings.

\section{Results}

i) Matrix Methodology in the involvement of parents, schools and community in student academic achievement.

Table 1. Pattern of parental involvement indicated by color bar

\begin{tabular}{|l|l|l|l|l|l|l|}
\hline Respondent & Parenting & Communication & $\begin{array}{c}\text { Decision } \\
\text { making }\end{array}$ & $\begin{array}{c}\text { Learning at } \\
\text { home }\end{array}$ & $\begin{array}{c}\text { Community } \\
\text { collaboration }\end{array}$ \\
\hline N1 & & & & & & \\
\hline N2 & & & & & & \\
\hline N3 & & & & & & \\
\hline
\end{tabular}

Yes

No

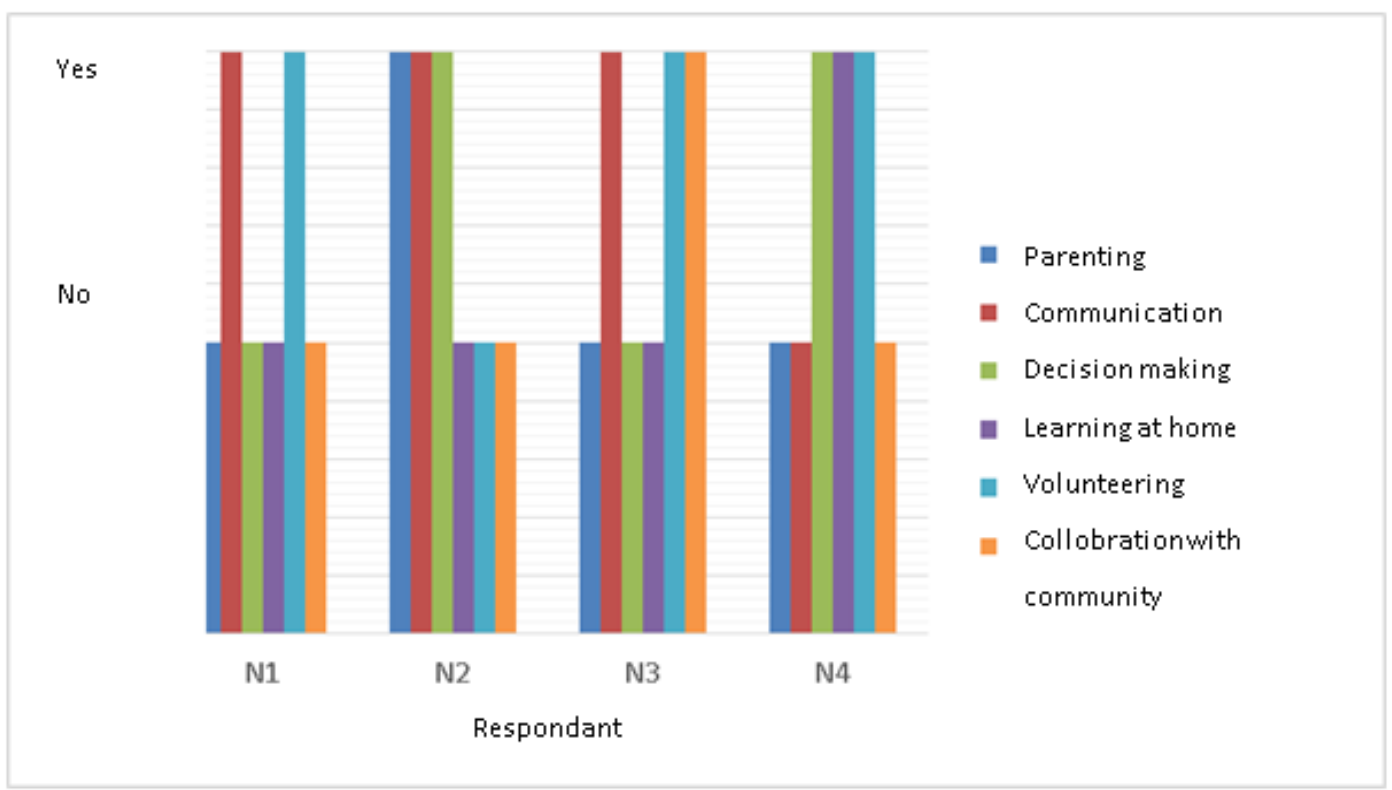

Figure 1. Summarize analysis of parental involvement as per each aspect 
Referring to Table 1, Parenting aspect show a high rate of $75 \%$ and three respondents support that parenting aspect is important in building collaboration between parents and schools. While only one respondent is less supportive of this factor. This is supported by the following statement:

"I feel that good parenting, communication skills and parental involvement in the academic aspects of their children." (R1)

"Good parenting will ensure that children take responsibility for their overall progress and development in curriculum and extra curriculum activities." (RI)

For the communication aspect, interviews show an equal rate of $50 \%$ where two respondents support and agree that communication aspect is necessary in building the cooperation between parents, schools and communities in order for the students to excel in academic achievement. This is stated in the statement:

\begin{abstract}
"Good communication is important between school and parents because parents need to be updated in terms of their child's performance and progress. Finally, the earlier parents involve in their children's education the better they can contribute in achieving academic excellence." (N1)
\end{abstract}

"I think a good communication channel is important and that is why I always keep the teacher responsive and informative by providing feedback to parents as they need to know their child's abilities and if necessary, parents can take corrective action before it's too late. This will ultimately lead to good relationships between parents and teachers." (N3)

However, two respondents are less supportive as they have stated that the communication aspect is unnecessary in certain situations. In terms of decision making, interview findings show an equal rate of $50 \%$ where two respondents support and agree that the decision-making aspect is needed in building the cooperation between parents, schools and communities for academic achievement. This is supported by the following statement:

"The main factor is the co-operation between teachers and parents because it requires a form of cooperation as teachers alone cannot determine the academic achievement of the child." Parents must also play an important role in this aspect. Second, it is important for parents to make timely decisions which are relevant to the needs of their children's education. Finally, strong community support is also important as the society in which children grow, has a huge impact on the overall development of children, especially if there is support and funding for useful educational programs for children because not all children are fortunate to have parents with a good background and educational income to provide them for their children." (N2).

However, two respondents are less supportive in their observation for the decision making aspect as it only contribute to cooperation between the school and the parents only in certain situations. However, the discretion is between parents and community schools when the need arises. This is stated in the statement:

"But now schools are more comfortable if parents are not involved in academic decision making. Schools do not want parents to be involved in their management." (N2)

In the Learning from home aspect, interviews show that $75 \%$ of the respondents support and agree that home-based learning is indispensable in building cooperation of parents, schools and communities for academic achievement. This is stated in the statement:

\begin{abstract}
"Actually, parents can be trained to be very proficient, creative, innovative, interesting and inspirational teachers at home but parents need to spend time and energy to achieve this. I believe that is a real challenge as most parents are too busy with their career and they leave this responsibility to the teacher at school or a tuition centre. Most of the time, parents claim that their children are not afraid of parents and fail to play the role of educators at home. Ultimately, parents who have to determine their role are as parents who are attentive or parents who are concerned about the fun of the children." (N2).
\end{abstract}

Yet another respondent is less supportive in which he notes that in terms of learning from home, collaboration between school and parents is not as satisfactory as parents sometimes do not understand a question especially parents who are uneducated and they will give wrong answers that can mislead students.

On the volunteerism aspect, interviews show that $75 \%$ of the three respondents support and agree that volunteerism is needed in parents, school and community cooperation for academic achievement. This is stated in the statement:

"The benefit of the first volunteer spirit is the fact that it is one of the most effective actions to develop a strong social network between parents, teachers and society. Second, the benefits are the same motives among members in the network as they have a tendency of achieving the goal of helping the students to achieve academic excellence. Parents can volunteer to help students with homework and for this they can get training from their respective teachers. Schools can be volunteers to hold 
educational talks and a series of activities where both students and parents can participate such as Family Day, Sports Day and Open Day." (N3)

However, one respondent is less supportive in which the findings show that volunteerism is a collaboration between school and parents and is less satisfactory because the parents are always busy with their work and less supportive in school activities. On the collaboration aspect with the community, interviews show that $75 \%$ of the respondents support and agree that collaboration with the community is indispensable in building the collaboration among parents, schools and communities to improve academic achievement. This is stated in the statement:

"Collaboration is not something new, it's has existed for a long time but people use different terms to explain it. Schools are collaborating with various authorities to implement programs for students such as breakfast for poor students, free tooth care, book subsidies, etc. Nowadays, it has been more commercialized with the involvement of private entities, but this form of collaboration can be productive for students if it can be safeguarded in the context of developing a young mind to sharpen them into high achievement." (N4)

However, one respondent is less supportive where the findings indicate that collaboration with the community is collaboration among school, parents and other entities. This mostly does not exist because most many parents refuse to work with outsiders such as NGOs and others.

\section{ii) Matrix methodology of Academic achievement} factors

Table 2. Academic achievement pattern indicated by colours

\begin{tabular}{|c|l|l|l|l|}
\hline Respondents & Parenting Style & Motivation & Personality & Learning Style \\
\hline N1 & & & & \\
\hline N2 & & & & \\
\hline N3 & & & & \\
\hline N4 & & & & \\
\hline
\end{tabular}

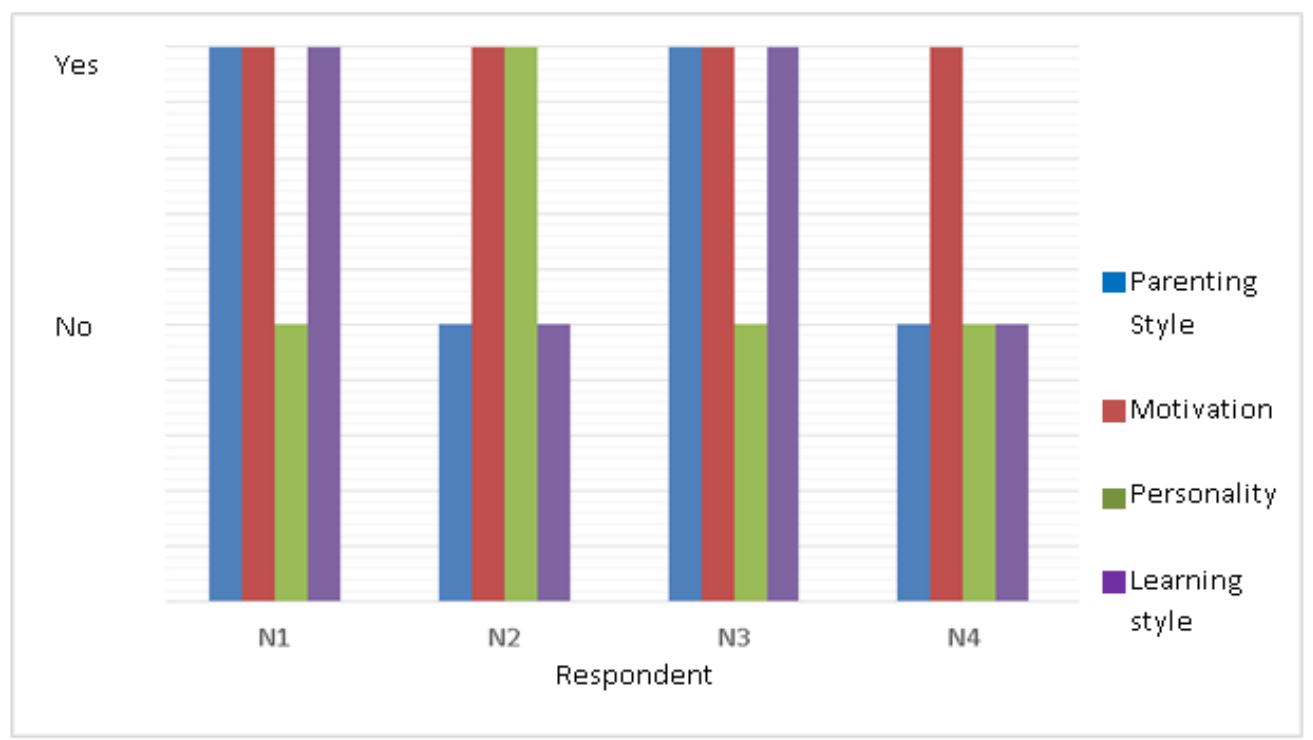

Figure 2. Summary of academic achievement factor as per the discussed aspects 
Referring to Table 2, Parenting Style Factor shows an equal rate of interview findings of $50 \%$ where two respondents agree that parenting style factor is necessary in the collaboration of teachers, schools and communities for a healthy academic achievement. This is stated in the statement:

\begin{abstract}
"In my opinion, there needs to be a two-way communication between parents and their children. Secondly, parents need to play a supportive role to foster the mental and physical development of the child. Finally, parents should first be an example to their children by practising healthy habits as children will follow this habit for the rest of their lives." (N1)
\end{abstract}

However, two respondents are less supportive where the findings show that parenting style factor is less important nowadays. The motivation factor shows that the highest rate from the interview which is $100 \%$ where the four respondents agree that the motivation factor is necessary in the academic achievement of students. This is stated in the statement:

"For me, the main factor is to get the attention and become famous in the school. Some students want to be popular and this is the main driving force as they are motivated by the praise they have received and their excitement during special moments to achieve high academic excellence." (N1)

While the personality factor shows a relatively low rate of $75 \%$ in the interview finding, three respondents disagree that personality factor was less visible among parents. This is stated in the statement:

"From my observations students who come with the right personality usually achieve high academic achievement." (N2).

While the learning styles factor shows an equal rate of $50 \%$ of the interviews, it was agreed that the learning style was indeed influencing academic achievement. This is stated in the statement:

"Students practice the most effective type of learning style in a positive family environment where parents have strong learning or reading habits." (N2).

While two respondents disagree with the fact that this positive learning style factor is lacking among these students as many parents are busy in their careers and less encouraged than they are and they themselves have no reading habits.

\section{Discussion}

All the four respondents agreed that parents play an important role in educating their children and that educators' task should not only be the responsibility of the teachers, because parent-teacher cooperation is essential for student academic achievement. The results of the interviews conducted also found that, learning at home and parental support are crucial. Parents play an active role in ensuring that their children learn at home. Schools should help prepare parents to fulfill these important responsibilities by providing guidance on how best to do so. Parents can help their children by setting a proper schedule for home learning. Also, children need to be trained and taught for subjects they are weak in. Parents may consult with teachers on ways to train their children. At the same time, parents need to ensure that there is a balance between learning and leisure to avoid stress on their children.

In addition, the findings of this study also indicated that, good communications are required among schools, parents and the community. This finding is supported by a past research which states that the aspect of communication and the formation of effective communication patterns are an important aspect of establishing collaboration between teachers and parents to produce efficient students. Epstein (2015) defined communication as a two-way, three-way or multi-way means which connects schools, families, and the community. A review of Epstein and Salinas's (2001) survey among a total of 3700 teachers in 600 schools in Maryland revealed that, teachers communicate with parents to foster their children's growth and learning by sharing information, insights, efforts related to difficulties faced during their learning, including academic and disciplinary issues.

Motivation has been found to be the most important factor in determining students' academic achievement. As such, parents need to encourage, listen to, respond to, praise, guide, monitor, and discuss with their children about their studies, instead of teaching them school subjects (Epstein, 2004).

\section{Recommendations}

Based on the findings of the study and the discussion which followed, some suggestions are made to be implemented by the schools, besides teaching, while the Ministry through parents' facility programmes with no exception to the outside community through non-governmental organizations in order to improve student academic achievement. This is clearly stated in Shift 9 of the Malaysian Education Blueprint (2013-2025) which emphasizes the involvement of parents, communities and private organizations in empowering schools. Organizing workshops and counselling seminars held by the schools can help develop a good communication between teachers and parents, which in 
turn, can improve students' academic achievement. Through this activity teachers can also hold active bilateral communication with parents through PTAs or NGOs to facilitate the holistic teaching and learning process. In addition, schools should also involve parents, guardians and local communities in organized activities such as Canteen Day, Family Day, Sports Day, Educational Day and so forth.

Organizing Student Report Card Day four times a year, each time right after the final examination in every term is completed. Through this activity, parents can discuss with teachers about the level of academic achievement of their children. This creates an opportunity for the sharing of opinions as well as information between teachers and parents that will help improve the academic achievement of their children. Since this study also relates to the importance of parent involvement in academic achievement through the collaboration between schools and communities that are still under-emphasized, especially in the Tamil Primary Schools, the researcher believed that further studies need to be implemented in each state to find out the extent parental involvement through collaborations between schools that causes effective impacts on students' academic achievement. These challenges need to be addressed together for the realization of Vision 2020 as well as the National Education Plan launched by PPPM (2013-2025) in producing excellent societies. Studies can also be carried out by looking at the relationships between students' achievement with the involvement of multi-racial parents in children's education whether in primary schools, secondary schools or tertiary institutions.

\section{Conclusions}

In general, through the Epstein Model approach, parent involvement is only viewed in the aspects of home-based learning, volunteerism, community collaboration and parenthood at moderate levels. Meanwhile, the communication aspect does not have a significant relationship although its presence can be seen, at a low rate. From this study, it can also be seen that, parent involvement in the aspect of communication is not encouraging, while in the parenthood aspect, it was found that parents' full responsibility was still lacking.

\section{REFERENCES}

[1] Anbalakan. K. (2008). Identiti India di Malaysia, Pulau Pinang: Penerbit Universiti Sains Malaysia.

[2] Baker, P. J., \& Moss, R. K. (2001). Creating a community of readers. In S. Redding \& L. G. Thomas (Eds.), The community of the school (pp. 319-333). Chicago:
Academic Development Institute.

[3] Clark. R. (2015). The Five Disciplines of Intelligence Collection: Intelligence \& Security Academy, LLC. 2(1), $118-124$

[4] Comer, J. P. (2005). The reward of parent participation. Educational Leadership.

[5] Comer, J. P. \& Haynes, M. (2002). 'Parent Involvement in Schools:An Ecological Approach" Elementary School Journal. 91 (3) : 271-277.

[6] Coleman, J.(2006). Social capital in the creation of human capital. American Journal of Sociology, Modified Version 94, S 95 - S120.

[7] Cooper, D. R. \& Schindler, P. S. (1998). Business Research Methods. Singapore: Mc Graw-Hill.

[8] Datuk Seri Mahdzir Khalid (2016). Persidangan Lembaga Pengelola Sekolah-Sekolah Tamil di Institut Aminuddin Baki, Genting Highlands. Penglibatan Ibubapa perlu ditingkatkan di sekolah.

[9] Dauber. S. L. \& Epstein, J. L. (1993). "Parents' attitudes and practices of Involvement in Inner - City Elementary and Middle Schools." In N Chavkin (Ed.) Families and Schools in a Pluralistic Society. Albany : State University of New York Press.

[10] Epstein, J. L. (2005). Forward. In Patrikakaou, E.,Weissberg, R., Redding, S. Wallberg, H. (Eds.), School-Family Partnerships for Children's Success: The Series on Social Emotional Learning (pp.vii-xi). New York: Teachers College Press.

[11] Epstein, J. L. (2001). School, family, and community partnerships: Preparing educators and improving schools. Boulder, CO: Westview Press.

[12] Gutman \& Midgley (2004). The Role of Protective Factors in Supporting the Academic Achievement of Poor African American Students During the Middle School Transition. Volume 29, Issue 2, pp 223-249.

[13] Laporan Pelan Pembangunan Malaysia ( $P P P M)$ 2013-2025 (KPM 2013, E-3)

[14] Malaysian SMART School : An MSC Flagship Application (1997). A Conseptual Blueprint. Smart School Project Team, 9 July. Kuala Lumpur : Ministry Of Education

[15] Marimuthu (1990). "Pengenalan Sosiologi Pendidikan." Shah Alam: Fajar Bakti.

[16] Merton, R.K. (2006). Sociological ambivalence and other essays. New York: The Free press.

[17] Minichiello (1991). In-depth Interviewing; Researching People. Cheshire, Melbourne: Longman.

[18] Mohd. Amin H. A. Shariff (1998). Perkembangan remaja: Pandangan, pemahaman dan interpretasi. Kuala Lumpur: Dewan Bahasa dan Pustaka.

[19] Norlizah Che Hassan (2008). Perkaitan cara gaya keibubapaan dengan konsep kendiri dan tingkah laku delinkuen remaja. Tesis Ijazah Kedoktoran Universiti Malaya, Kuala Lumpur. 
in Students' Academic Achievement Using School and Family Partnership Model (Epstein): A Qualitative Study

[20] Noraini Ahmad (2002). Siri Motivasi Dan Kecemerlangan Utusan: Kaunseling Kekeluargaan. Cheras: Utusan Publications \& Distributors Sdn. Bhd.

[21] Ranjit Singh Mali (1999). Enchancing Personal Quality. The Bedrock of Organisational Quality. Kuala Lumpur: Cetakrapi Sdn. Bhd.
[22] Razali.M.F.(2007). "Manfaatkan PIBG Untuk Kejayaan Sekolah." Pendidik 40. $44-45$.

[23] Santhiram, R. (1999). Education of minoritie: The case of Indians in Malaysia. Kuala Lumpur: Child Information, Learning And Development Centre. 